\title{
Some Pollutants to Defeat to get Clean Drinking Water
}

\author{
Juan Horacio Pacheco-Sánchez* \\ División de Estudios de Posgrado e Investigación del TecNM, México \\ *Corresponding author: Juan Horacio Pacheco-Sánchez, División de Estudios de Posgrado e Investigación del TecNM, México. \\ To Cite This Article: Juan Horacio Pacheco-Sánchez. Some Pollutants to Defeat to get Clean Drinking Water. Am J Biomed Sci \& Res. 2019 - 4(6). \\ AJBSR.MS.ID.000848. DOI: 10.34297/AJBSR.2019.04.000848
}

Received: 眥 August 20, 2019; Published: 眥 August 26, 2019

\section{Introduction}

The colorants, especially synthetic origin present in waste water, are responsible for many harmful effects to the environment, flora and aquatic fauna. Among the most important effects are the reduction of dissolved oxygen, eutrophication, the formation of recalcitrant and toxic compounds to cells and obstructing the passage of light to the water bodies and aesthetic impairment [1,2]. As an example, red 2 is an azo colorant that may cause intolerance in people who are affected by salicylates. Moreover, it is a histamine liberator, and may intensify symptoms of asthma. It is also involved in cases of hyperactivity in children when used in combination with benzoates. Many countries like the United States have limited their use [3] because it creates problems requiring medical treatment. When azo-type colorants also called Reagent, are dumped into the water bodies produce amines as consequence of the rupture of azo bond, which cause many effects in some human organs such as the brain, liver, kidney, central nervous and reproductive systems [4,5]

Synthetic dyes also affect the photosynthetic activity of some aquifer's plants due to the presence of aromatics, metals, chlorides, etc. [6]. The discovery of synthetic dyes has limited the role of natural dyes due to its characteristics such as low production cost, brighter colors, better resistance to environmental factors and easy application. However synthetic dyes can be often highly toxic and carcinogenic [7]. The dyes have become a major source of severe water pollution as a result of the rapid development of many industries that use them in order to colorize their products [8]. Effects described by pollution of azoic dyes mean a problem that requires attention and treatment. Chemical structure of red 2 or amaranth red E-123 (trisodium 2-hydroxy-1-(4-sulfonato-1-naphthylazo) naphthalene-3-6-disulfonate, molecular weight $604.5 \mathrm{~g} / \mathrm{mol}$, and formula $\mathrm{C}_{20} \mathrm{H}_{11} \mathrm{~N}_{2} \mathrm{O}_{10} \mathrm{~S}_{3} \mathrm{Na}_{3}$ [1]. Effluent discharges of colorant have triggered a great concern for human health and marine life [9].

By this reason, it has been tremendous growth in both the setup of equipment, corrective facilities, and the development of alternative technologies that respect the environment. Many of these technologies are based on the retention of a contaminant in a solid medium that makes it easy to handle and / or the possible recovery of the material, such as adsorption [10]. One of this material is chitosan. Chitosan molecule exceed valence, which allows them to join colorants and metals $[11,12]$. Chitosan can be obtained from the partial deacetylation of chitin. At present the chitosan product applications lies primarily in: nutraceuticals, food protectors generally, formulations for cosmetics, medical applications, agricultural uses, feed, flocculation, textiles, pulp and paper. Additionally, application to water purification is in research. Chitosan can be obtained from the partial deacetylation of chitin [13]. Chitin is the second most abundant natural polysaccharide in the nature. Chitosan copolymer is constituted by units $\beta-(1-4)-2$-acetamide-2-deoxy-D-glucopyranose and $\beta$-(1-4)-2-amino-2-deoxy-D-glucopyranose. The former has a molecular weight of 203.2, and formula $\mathrm{C}_{8} \mathrm{H}_{13} \mathrm{NO}_{5}$; the latter has a molecular weight of 161.1, and formula $\mathrm{C}_{6} \mathrm{H}_{11} \mathrm{NO}_{4}$. When chitosan is dissolved in an acidic medium the amino group is protonated, this fact generates a positive charge, while the azo dyes with sulfonate groups dissolved in water have a negative charge. Therefore, there are groups $\mathrm{NH}_{3}^{+}$and. $\mathrm{OO}_{3} \mathrm{~S}$, which have attracted each other, giving rise to adsorption of azo dyes with sulfonic groups in the chitosan.

The interaction between chitosan (adsorbent) and azoic dye (adsorbate), through their reaction sites $\mathrm{NH}_{3}^{+}$(ion of ammonia from amino group protonated) and ${ }_{. . O_{3} S}$ (sulfur trioxide ion of sulfonate group) respectively, provides the type of existing adsorption [14]. This is done first calculating its geometry optimization, and then building the potential energy surface by fixing $\mathrm{NH}_{3}^{+}$and bringing in.$O_{3} S$. The reaction among these molecular ions produces sulfamic acid which in zwitterion form ${ }^{+} \mathrm{H}_{3} \mathrm{NSO}_{3}^{-}$is more stable than the neutral acid form $\mathrm{H}_{2} \mathrm{NSO}_{2} \mathrm{OH}$ in solid state [15-19]. Physical properties (structural and spectroscopic) and chemical reactions of sulfamic acid have been extensively reviewed [20-22]. The structure of both the zwitterion and neutral form has theoretically been studied previously [23-27]. The neutral case has been studied as an isomer $\mathrm{HSO}_{3} \mathrm{NH}_{2}$ [14]. It is known the use of ammonia $\left(\mathrm{NH}_{3}\right)$ to remove sulfur dioxide $\left(\mathrm{SO}_{2}\right)$ [28,29]. Some researchers [30,31] have 
also worked with interactions and reactions of sulfur trioxide and ammonia not alone. In our case [32], an ion of ammonia $\left(\mathrm{NH}_{3}^{+}\right)$in the chitosan adsorbs an azoic dye having sulfonate group through S.$O_{3} S$.

\section{References}

1. Á Arango Ruíz, LF Garcés Giraldo (2009) Lasallista de Investigacion 6(2): 31.

2. CI Pearce, JR Lloyd, JT Guthrie (2003) The removal of colour from textile wastewater using whole bacterial cells: A review. Dyes and Pigments 58(3): 179-196.

3. SL Rodríguez Amézquita, Tesis de Licenciatura (2008) Universidad de San Carlos. Guatemala.

4. N Sánchez, M Vázquez y R Torres (2010) Revista de la Facultad de Ing. de la Universidad de Antioquia p. 55.

5. A Mittal, J Mittal, L Kurup (2006) Batch and bulk removal of hazardous dye, indigo carmine from wastewater through adsorption. J Hazard Mater 137(1): 591-602.

6. Crini G, Badot PM (2008) Application of Chitosan, a Natural Aminopolysaccharide, for Dye Removal from Aqueous Solutions by Adsorption Processes Using Batch Studies: A Review of Recent Literature. Progress in Polymer Science 33: 399-447.

7. Q Liu, B Yang, L Zhang, R Huang (2015) Adsorption of an anionic azo dye by cross-linked chitosan/bentonite composite. Int J Biol Macromol 72 : 1129-1135.

8. GZ Kyzas, PI Siafaka, EG Pavlidou, KJ Chrissafis, DN Bikiaris (2015) Synthesis and adsorption application of succinyl-grafted chitosan for the simultaneous removal of zinc and cationic dye from binary hazardous mixtures. Chem Eng J 259: 438-448.

9. Wan Ngah WS, Teong LC, Hanafiah MAKM (2011) Adsorption of dyes and heavy metal ions by chitosan composites: A review. Carbohydrate Polymer 83(4): 1446-1456.

10. EG Tuesta, Vivas M, R Sun, A Gutarra (2005) Modificación química de arcillas y su aplicación en la retención de colorants. Revista Sociedad Química de Perú 71(1): 26-36

11. Pacheco Sánchez, JH, B García Gaitán, RE Zavala Arce (2014), Memories of Polymer Meeting MACROMEX pp. 402-407.

12. Suárez Rosario, Pacheco Juan (2017) Revista de Simulacióny Laboratorio $4: 46$.

13. NA Travlou, GZ Kyzas, NK Lazaridis, EA Deliyanni (2013) Magnetic Graphene Oxide: Effect of Preparation Route on Reactive Black 5 Adsorption. Chem Eng J 6(4): 1360-1376.
14. Pacheco Sánchez JH, B García Gaitán, R Suárez Reyes, RE Zavala Arce (2015) Memorias del XXVIII Congreso Nacional de la Sociedad Polimérica de México pp. 96-101.

15. MA Wong, KB Wiberg, MJ Frisch (1992) Solvent effects 1 The mediation of electrostatic effects by solvents. J Am Chem Soc 113(13): 4776-4782.

16. FA Kanda, A King (1951) The Crystal Structure of Sulfamic Acid. J Am Chem Soc 73(5): 2315-2319.

17. RL Sass (1960) A neutron diffraction study on the crystal structure of sulfamic acid Acta Crystallogr B 13: 320-324.

18. JW Bats, P Coppens, TF Koetzle (1977) Acta Crystallogr. B 37: 1333.

19. A Reuven, D Marcellus, RS Parker, AL Kwiram (1981) J Chem Phys 74: 179.

20. LF Audrieth, M Sveda, HH Sisler, MJ Butler (1940) Chem Rev 26: 49.

21. GA Benson, WJ Spillane (1980) Sulfamic acid and its N-substituted derivatives. Chem Rev 80(2): 151-186.

22. R Santmeyer, R Aarons (1969) in Kirk-Othmer Encyclopedia of Chemical Technology. A Standem Interscience New York, USA 19: 242.

23. SJ Hickling, RG Woolley (1990) An ab initio Hartree-Fock study of the zwitterion of sulphamic acid $+\mathrm{H}_{3} \mathrm{NSO}_{3}$. Chem Phys Lett 166(1): 43-48.

24.JE Douglas, GL Kenyon, PA Kollman (1978) The ammonia-sulfur trioxide interaction An ab initio study. Chem Phys Lett 57(4): 553-556.

25. P Kaliannan, S Vishveswara, VSR Rao (1983) Ab initio SCF-MO study of the molecular structures of aminomethanol aminesulfonic acid and N-methyl-sulfamate. J Mol Struct 105(3,4): 359-374.

26. DWJ Cruickshank (1985) A reassessment of $d \pi-p \pi$ bonding in the tetrahedral oxyanions of second-row atoms. J Molec Struct Eisentein 130(1,2): 177-191.

27. P Kaliannan, S Vishveswara, VSR Rao (1985) Sulphamic acid in zwitterion-An ab initio SCF MO study. Current Sci 54(22): 1174-1176.

28. FR Alix, JL Duncan, Ch R McLamon (2003) Removing NOx SO2 and $\mathrm{Hg}$ from a gas stream using limestone regeneration. US Patent No US6605263 B2

29. EM Hartley Jr, MJ Matteson (1975) Ind Eng Chem Fundam 14(1): 67.

30. M Solimannejad, A Boutalib (2004) G2 Molecular Orbital Investigation of $\mathrm{OCH}^{+}-\mathrm{XH}, \mathrm{OCH}^{+}-\mathrm{X}_{2}$, and $\mathrm{OCH}^{+}-\mathrm{XY}(\mathrm{YX})(\mathrm{X}=\mathrm{Y}=\mathrm{F}, \mathrm{Cl}$, and $\mathrm{Br}$ ) Proton Bond Complexes. J Phys Chem A 108(21): 4769-4772.

31. P Antoniotti, S Borocci, F Grandinetti (2005) Comment on "Computational Investigation of $\mathrm{SO}_{3}-\mathrm{NH}_{3}-\mathrm{nXn}(\mathrm{n}=0-3 ; \mathrm{X}=\mathrm{F}, \mathrm{Cl})$ Interactions". J Phys Chem A 109(10): 2410-2411.

32. Suárez Reyes R, Zaragoza IP, Pacheco Sánchez JH (2018) Mediterranean Journal of Chemistry. 7(4): 243. 